\title{
Chapter Two \\ The Peasant-Soldier: Alexander Tvardovsky and a New Chapaev
}

\author{
Not once did the soldiers or officers \\ Add a word about Duty or Faith, \\ About Fatherland, Conscience or Honor. \\ To their usual answer: "Yessir!" \\ Но ни разу про Долг и про Веру, \\ Про Отечество, Совесть и Честь \\ Ни солдаты и ни офицеры \\ Не добавили к этому “Есть!”
}

-Boris Slutsky

Gladkov's Cement took its place on what would become a long shelf of "production" novels, created according to the method of socialist realism during the Soviet interwar period. To say that most of them are dreary, forgettable, and deserve their fate now as artifacts rather than as literature is not to say very much.

However, those endless production novels had attempted two things that do interest us here. First, they tried to make the very process of building a new Soviet society, and becoming new Soviet citizens, synonymous with the experience of war-filled with enemies to be defeated, "fronts" to fight on, heroic deeds to be done, and victories to be celebrated. Podvig in the service of class warfare and postwar reconstruction. In this sense, these novels surely tried to foster the health of the Soviet state. Second, the novels offered Soviet readers heroes-heroes who engaged in extraordinary feats, fully conscious of their role in advancing the Soviet cause. ${ }^{1}$

1 One of the quintessential heroes of this type is Pavel Korchagin, hero of Nikolai Ostrovsky's 1936 novel How the Steel Was Tempered (Kak zakalialas' stal'). Even today Russian women continue to complain about having to choose between Pavka Korchagin and Grishka Melikhov when they think about their male counterparts. (Melikhov is the hero of Mikhail Sholokhov's 1940 Quiet Flows the Don [Tikhii Don].) As Vladimir Kataev has written, the only interesting character in Russian literature was Ostap Bender, leaving women readers crying out, "Rhett Butler, where are you?" V. B. Kataev, Igra v oskolki: Sud'by russkoi klassiki v epokhu postmodernizma (Moscow: Izd. Moskovskogo Universiteta, 2002), 80-81. 
Those heroes never really stuck. Violence against ordinary people continued throughout the period: purges and collectivization and prison camps. We can see this violence as part of the militarization of civilian life, but it did not prove conducive to the creation of resonant literary heroes. New heroes would have to wait for actual war in order to be "successful" as literary characters. As Randolph Bourne noted, the government might make all sorts of impositions on citizens during times of peace, but only times of war bring on the sense of the "sanctity of the State" and its concomitant feelings of collective will and mobilization for the patriotic good.

But Soviet writers did not have long to wait. Less than twenty years after the conclusion of the Civil War, Russians would find themselves again mobilized to fight. The Second World War stands as the pivotal event of the Russian twentieth century, and its meaning continues to be fought over even into the twenty-first. Consequently, the way Russian writers tried to make meaning out of the events of that war will concern much of the rest of this book.

In this chapter, I focus on the work of Alexander Tvardovsky and his monumental wartime poem Vasily Tyorkin: A Book about a Soldier-truly a worthy comrade to Chapaev.

In 1929, Osip Brik had called for a marriage between heroics and the everyday in Soviet literature, between podvig and byt. The former urges citizens to sacrifice themselves in feats of glory and features the capitalized concepts of Fatherland, Duty, and Honor, of Death and Life on Earth, while the latter grounds those concepts in the particularities of lived experience. Ideally, each should inform the other, though as Brik pointed out, such a marriage was far from easy to negotiate. Great feats, narrated using what we are calling the rhetoric of podvig, would never transcend entirely the sense of the collective central to Soviet identity, while everyday life, byt, would in the Soviet context be lived framed by a sense of higher calling and obligation. War provided the conditions necessary for that marriage, and what made it possible was duty, described with what we can call the "rhetoric of est'?" The Russian word est', after all, can be translated as "is" or "exists," "being" or "existence"; "there is," "there are." It is also what Russian soldiers reply when called to attention or given an order: "Yessir!" "Aye, aye, sir!" Boris Slutsky's four-stanza poem, the third stanza of which is quoted in the epigraph to this chapter, ends thus: 
With a terse awareness of duty, Silently thinking of the Fatherland, They lived well, happily, and long

Or they instantly died in battle. ${ }^{2}$

In Soviet war literature, byt is not a rhetorical strategy; it is the details of the trenches, what some call the blood and mud of wartime existence. But informed by the rhetoric of est', framed by the need to answer the call of the Fatherland, to perform one's duty, the "being" of byt is raised to the level of est'. With this silence, this "terse awareness", the soldier accepted his fate.

Alexander Tvardovsky was an eyewitness to war. As we explore below, he used his powers of observation and description to bring to life a new hero, a new Chapaev for the Second World War, who cheerfully and without complaint dealt with all the horrors of battle, all the complications of reconnaissance, all the pain of wounds and near-death. Vasily Tyorkin was a portrait of the war experience, and in it Tvardovsky used both rhetorical strategies which we've been examining to great effect. He used details of wartime byt to encourage and celebrate podvig while maintaining a straightforward attitude of the soldier's duty to answer "yessir" when the order came. And for the generation who fought the Second World War, Tyorkin was an enormously successful wartime hero.

Tvardovsky approached the war and its trials from an utterly pragmatic point of view. For example, in the chapter of Vasily Tyorkin entitled "About War," the narrator says, "Well, why even discuss it,-_ / It's all totally clear. / We have to beat the Germans, brother, / No deferment here." ${ }^{3}$ No moral ambiguity, no introspection, no chatter, no self-examination, no doubts.

\section{The Poetry of Heroics and the Heroics of Poetry}

Less than two months after the war with Germany began, the Literary Gazette published an editorial on "the place of the writer in the Fatherland War." It read in part:

Writers are provided with plenty of material by the thousands of occurrences of individual and collective heroism shown by the Red Army and Navy. A writer should use his skill to create generalizations from these facts so as to reveal artistically in every example of heroism

2 Boris Slutsky, Bez popravok... (Moscow: Vremia, 2006), 135.

3 Tvardovskii, Vasilii Tyorkin: Kniga pro boitsa (Moscow: Nauka, 1976), 36-37. 
the national character of the Soviet people, the nobility of their ideas, which inculcate a scorn of death and hatred of the enemy. ${ }^{4}$

As this editorial demonstrates neatly, modern war generates propaganda, most of which is designed to inflame feelings of nationalism and a hatred of the enemy that reduces him to something less than human. During the war, using three hundred workers in three daily shifts, the Soviet news agency TASS produced 1,400 different war posters, many of which did precisely that. ${ }^{5}$

Ilya Ehrenburg and Konstantin Simonov, among others, famously treated the theme of hatred of the enemy with powerful propaganda pieces. Ehrenburg's newspaper essay "Kill!" (published in the Red Army newspaper, Krasnaia zvezda, on July 24, 1942), for example, begins with details from German letters, marked by real names: Lt. Otto von Schirach, Mathias Dimlich, Helmut Zimlich, Otto Essman, and Lt. Helmut Weigand. The letters demonstrate a disdain for Russians (calling them "animals," "beasts," "types"), and Ehrenburg responds to what he characterizes as the Germans' philosophizing-“Are these really people?"-with a clear answer: "We know everything. We remember everything. We have understood: the Germans are not human. [. . .] We will not speak. We will not be outraged. We will kill." Throughout the article, his rhetoric builds through repetition and escalation: "If you haven't killed at least one German today, your day was wasted." This statement is followed by seven more "if" statements. The repetitive syntax continues, "Do not count days. Do not count versts. Count only one thing: the Germans you have killed," culminating in a call for bloodbath:

"Kill the Germans!" the old mother requests it. "Kill the Germans!" the child begs it of you. "Kill the Germans!" cries the earth of your homeland. Don't blunder. Don't miss. Kill. ${ }^{6}$

Simonov's poem "Kill Him," also written in July 1942, makes similar exhortations in the hypothetical "if," contrasting the Soviet soldier to the

4 “Mesto literatora v Otechestvennoi voine," Literaturnaia gazeta (20 August, 1941): 1.

5 On TASS during wartime see, for example, Robert Bird, "The Functions of Poetry: TASS Windows and the Soviet Media System in Wartime," in Windows on the War: Soviet TASS Posters at Home and Abroad, 1941-1945, ed. Peter Kort Zegers and Douglas Druick (New Haven and London: Art Institute of Chicago and Yale University Press, 2011), 92-103.

6 Krasnaia zvezda No. 173 (5236) (24 July 1942). 
German: "If your brother killed a German - / Then he's the soldier, not you, / So kill a German so that he / Not you will lie on the earth, / So that groans will sound, mourning the dead, / Not in your house, but in his. / That's what he wanted, he's at fault, / Let his house burn, not yours, / And let his wife, not yours / Become a widow ..."7 This heightened language of hatred finds its place in military newspapers and sometimes with soldiers at the front who spent the war carrying Simonov clippings in their pockets, but "scorn of death," which sounds great in an editorial meeting, was much rarer in the actual trenches.

Effective as this type of propaganda may be in mobilizing citizens to fight, it did not constitute a poetry of heroics. After all, it is actually quite difficult for human beings to sustain anger and hatred indefinitely. The language from the Literary Gazette is telling: the description of the "nobility" of Soviet ideas is supposed to breed more than just hatred. Yet the everyday facts from which this rhetoric is to emerge, the "material," the individual acts, were part of the fabric of life in wartime and were equally likely to result in a different set of reactions and literary responses.

Some writers followed this prescribed pattern to highlight podvig; others did not. Readers of Soviet fiction, even during wartime, responded better to humor and the everyday (with just a sprinkling of heightened rhetoric) than they did to calls for hatred. Thus in the aftermath of war, it was Vasily Tyorkin who survived.

\section{A New Chapaev: Tvardovsky and his Tyorkin}

The biography of the poet, journalist, and editor Alexander Tvardovsky (1910-1971) could have turned out differently, more like a typical tragic peasant story of the early Soviet years. His Smolensk family was made up of hardworking, successful peasants, and he, perhaps, was fortunate to have left home before they were reclassified as "kulaks," arrested and resettled in the far reaches of Soviet Siberia. Tvardovsky himself went on to a successful career, but that shadow followed him throughout his life.

As a young man, Tvardovsky studied at the Smolensk Pedagogical Institute in the hopes of a literary career and began to publish poems as early as 1925 in Smolensk newspapers. Tvardovsky's choice of a career path among

7 Simonov, Sobranie sochinenii v dvenadtsati tomakh, vol. 1 (Moscow), 105-107. See Katharine Hodgson, Written with the Bayonet: Soviet Russian Poetry of World War Two (Liverpool: Liverpool University Press, 1996), 71-72. 
intellectuals and party functionaries in the city resonated in sad and permanent ways when Tvardovsky's family was swept up in the anti-kulak campaign. According to his brother Ivan, the family was subjected to artificially high "individual taxes" beginning in the spring of 1930, and by March 19 of that year they had been sent into administrative exile.

In retrospect, Tvardovsky's choice to strike out on his own path took on an entirely different meaning; his life in the city now represented a rejection of home and family and, certainly in Ivan's eyes, a betrayal of his parents and his heritage. The natural desires of a young man-to make something of himself, to study and join the new society as a contributing member-in essence made an orphan out of Tvardovsky. From that point on, Tvardovsky was on his own, every step accompanied by a label. On every form Tvardovsky ever filled out - and in the Soviet Union there were always plenty of forms-in answer to the question "social origin of parents," Tvardovsky wrote, "Fatherkulak, sent into administrative exile from the Western region." ${ }^{8}$

Best known in the West for his role in the 1950s and 1960s as editor of the liberal literary journal Novyi Mir (New World), the journal that published Solzhenitsyn and Sinyavsky, Panova and Pasternak, Tvardovsky also functioned in the Soviet context as an example of the peasant who became cultured, a peasant who turned away from agricultural work and instead redirected his energy toward a role in the new Soviet society. ${ }^{9}$ In that sense, Tvardovsky was a real Chapaev: a character who harnessed the spontaneous energy of the hardworking peasant to a revolutionary, indeed Bolshevik, vehicle. Somehow overcoming the label "son of a kulak," Tvardovsky became

8 See Regina Romanova, Aleksandr Tvardovskii: trudy i dni (Moscow: Volodei, 2006), $71,77$.

9 Tvardovskii had two stints as editor of Novyi Mir: 1950-1954 and 1958-1970. For a negative portrayal of the editorial board of Novyi Mir in the 1960s, see Alexander Solzhenitsyn's fictional memoir The Oak and the Calf: Sketches of Literary Life in the Soviet Union, trans. by Harry Willets (New York: Harper and Row, 1975). In defense of Tvardovskii, Vladimir Lakshin, one of the assistant editors of Novyi Mir during the years when NM was printing Solzhenitsyn's work, published the essay "Solzhenitsyn, Tvardovskii i Novyi Mir," in The Twentieth Century: A Socio-political Digest and Literary Magazine, vol. 2 (London: TCD Publications Ltd., 1977). The essay was also published in French and in English. I quote from the English translation by Michael Glenny (Cambridge, MA: MIT Press, 1980). In a warm and touching memorial essay, Viktor Nekrasov recalled that Tvardovsky sighed over this very fact: "Alas, abroad I'm hardly known as a poet, but mostly as the editor of some progressive journal." See "Aleksandr Tvardovskii," in Viktor Nekrasov, Kak ia stal sheval'e: Rasskazy. Portrety. Ocherki. Povesti (Ekaterinburg: U-Faktoriia, 2005), 83. 
a Soviet hero himself, and he created one of the most beloved literary heroes of the Soviet twentieth century, the soldier Vasily Tyorkin.

With roots in the countryside around Smolensk, Tvardovsky naturally portrayed the peasantry in his early work. ${ }^{10}$ And although he continued to keep the collectivized peasants in mind, Tvardovsky turned from "village" to military themes in the late 1930s, expressing a certain satisfaction with this transition through his emphasis of the kinship between peasants and military personnel: "These were those very same Soviet people, living under the conditions of army and frontline life." 11 This connection with the masses, whether in the village or in uniform, reified Tvardovsky's origins as a "man of the people." Forced to turn his back on his own peasant family, Tvardovsky discovered a role for himself as a literate Chapaev, portraying the people he knew in his poetry, and these sometimes amusing and often perceptive psychological portraits populated his pages and charmed his readers. ${ }^{12}$ This kind of heroism, drawn in part from Civil War literature and in part from the traditions of Russian folklore, gave new life to socialist realism in the context of the war.

In the best of literary circumstances, war gives birth to memorable characters, either living military heroes or their fictionalized counterparts. Just as Chapaev remained vivid in the Russian imagination long after the Civil War

10 Tvardovskii described the fate of the peasantry under Stalin in his 1936 poem "The Country of Muravia." While the political moral here is orthodox, leading the peasant Nikita Morgunok to embrace collectivization, "Muravia" is not just a propaganda poem. Rather, it has been seen as a "modern counterpart of [Nikolai] Nekrasov's great epic of peasant life, Who Lives Happily in Russia?" Gleb Struve, Russian Literature under Lenin and Stalin (Norman: University of Oklahoma Press, 1971), 311. Only much later would Tvardovskii write about his own family's arrest and exile.

11 Aleksandr Tvardovskii, "Kak byl napisan 'Vasilii Tyorkin"' in Vasilii Tyorkin: Kniga pro boitsa (Moscow: Nauka, 1976), 240. Note that when studying at the Smolensk Pedagogical Institute, Tvardovskii worked with a literature professor (Vasilii F. Chistiakov) on his Slovar' komedii 'Gore ot uma' (1939), having received "the assignment to write out ... every instance of the usage of the preposition ' $k$ ' ('to') on separate cards." (See V. Lakshin, Vtoraia vstrecha (Moscow: Sovetskii pisatel', 1984), 129, quoted in Romanova, Trudy $i d n i$, 89.) It was Chistiakov who recommended that Tvardovskii apply to the Moscow Institute of History, Philosophy, and Literature. This intimate familiarity with the most quoted and quotable work of verse drama of the nineteenth century surely taught Tvardovskii to sketch verbal portraits with confident strokes.

12 In reference to Evgenii Shvarts, Caryl Emerson has written about how the "fairy-tale format provided optimism without the ambitious bombast of the production novel." Cambridge Introduction to Russian Literature (Cambridge: Cambridge University Press, 2008), 208. Tvardovskii, too, by focusing his attention on a "simple" hero from village life, gives his Tyorkin an energy that doesn't need propping up with political dogma. 
had faded, so too the character of Vasily Tyorkin entered the pantheon of Russian war heroes during the Second World War and lived on as a folk hero in the minds of the postwar Russian populace.

Called by many commentators an "ideal socialist realist hero," Tyorkin was actually somewhat more complicated. For Soviet readers, especially those in the military, Tyorkin played the role of a brother and friend, an "official" hero who was likeable and believable and-perhaps most importantly-who cheered them up wherever they encountered him. Ordinary soldiers read Tyorkin in frontline newspapers and recited sections of the poem to each other at their campfires and in the trenches. ${ }^{13}$ We can find evidence of these reactions in the memoirs of countless soldiers, but among the most valuable sources is Alexander Solzhenitsyn, whose relationship with Tvardovsky by the time he wrote his memoir The Oak and the Calf had soured considerably. Even so, Solzhenitsyn wrote the following about Vasily Tyorkin:

Tvardovsky had succeeded in writing something timeless, courageous and unsullied, helped by a rare sense of proportion, all his own. ... Though he was not free to tell the whole truth about the war, Tvardovsky nevertheless always stopped just one millimeter short of falsehood. ... The result was a miracle. I am not speaking only for myself; I had excellent opportunities to observe its effects on soldiers in my battery during the war.... Of the many things offered them, they obviously had a special preference for War and Peace and Vasily Tyorkin. ${ }^{14}$

What's more, as V. M. Akimov has explained, Vasily Tyorkin "made it through all the trials of war without high-sounding slogans or a single mention of the name of Stalin."15 Wartime poet Boris Slutsky read Tyorkin with satisfaction, commenting, "This was true poetry." 16

13 War participant G. E. Shelud'ko wrote, "Almost every soldier, while resting, marching, fighting, would recite the words of the poem by heart." Qtd. in A.L. Grishunin, "Vasilii Tyorkin A. Tvardovskogo," 463.

14 Aleksandr I. Solzhenitsyn, The Oak and the Calf, 14-15.

15 V. M. Akimov, Ot Bloka do Solzhenitsyna: Sud'by russkoi literatury XX veka (posle 1917 goda) (St. Petersburg: St. Petersburg State Academy of Culture, 1994), 82. Mark Lipovetsky sees Tyorkin as a Stalinist appropriation of what he calls the "trickster trope." See his Charms of the Cynical Reason: The Trickster's Transformation in Soviet and Post-Soviet Culture (Boston: Academic Studies Press, 2011), 199; also 40.

16 Quoted in L. Lazarev, "Vo imia pravdy i dobra: o poezii Borisa Slutskogo," in Slutsky, Bez popravok..., 46. 
Nationalism, patriotism, and hatred are the primary tools the state uses to mobilize a population for war. In Tvardovsky's Vasily Tyorkin, readers found those national characteristics and that patriotism personified and humanized-a soldier-hero who was an authentic everyday guy. He was "our lad," as Tvardovsky wrote in his notebooks. Unlike Chapaev, Vasily Tyorkin worked alone; he was an individual, with his own ideas and ways of doing things, and he didn't seem to have a commissar looking over his shoulder. In that sense, Tyorkin augmented the Civil War model of the heroic soldier as first seen in Furmanov's pair of characters yoked to one another in the spontaneity/consciousness mode. Chapaev represented energy and inventiveness, the instinctual ability to see the best way to lead his men in battle and to discipline them when quartered among civilians, and Furmanov's political commissar, Klychkov, was constantly at his side, correcting and directing him toward the truth of the party. The 1934 film version of Chapaev added humor-and the charms of some of the first vivid talking heroes from the big screen - to that image. Less than a decade later, in the character of Tyorkin, Tvardovsky retains the inventive, instinctual, cheerful peasant, but allows him to work for his country on his own terms, without the interference of the party or a commissar. He is a new Chapaev, both humorous and serious, but also fully grown-up and politically mature.

Critics have commented on the absence of a "recognizably Soviet context" in Vasily Tyorkin, where the vocabulary and comparisons frequently draw on "ordinary peace-time existence, even when describing specifically military actions." A poem about a Soviet warrior . . . without war terminology and without Soviet political propaganda. In Katherine Hodgson's words, "Tyorkin is a figure with whom readers could identify, an instantly recognizable type who inspired trust and affection" $(196,170)$.

There was a reason for this. Tvardovsky saw war fiction as a vital part of national consciousness:

Life, reality, is not fully real until it is reflected in the mirror of art, only then does it receive its reality, so to speak, and obtain stability, become established, gain meaning for the long term. Without War and Peace, what would the year 1812 have been for the consciousness of many generations of Russian people? ${ }^{17}$

17 Tvardovsky, quoted in Igor' Sukhikh, Knigi XX veka: russkii kanon (Moscow: Nezavisimaia gazeta, 2001), 13 . 
This relationship between life and art suggests a social function of literature, a need for narrative in order to understand events as they occur and when we look back at them. We can recall Drew Faust's argument about war as a "narrative invention," transforming violence through a story of purpose. That story is what we tell ourselves about war in order to justify and legitimate actions that otherwise seem barbaric. ${ }^{18}$ The literary folk hero Tyorkin fulfilled this task for the author and his audience from the early'40s through the mid-' 60 s. ${ }^{19}$

\title{
War as Muse: The Birth of Tyorkin
}

Vasily Tyorkin: A Book about a Soldier was written and published during the early years of the Second World War, but the figure of Vasily grew out of an earlier group project. Thus the authorial initiative, in true Soviet fashion, was at first a "collective" one. While working at the newspaper In Defense of the Homeland (Na strazhe rodiny) during the Finnish war in 1939, Tvardovsky and some colleagues created a kind of comic strip hero named Vasya Tyorkin. ${ }^{20}$ This early "collective" version of Tyorkin-specifically called by the nickname Vasya rather than the full name Vasily-was truly unique and unusual ("neobyknovennyi") and was identified by his authors in their characteristic quatrains as a hero from the start:

\author{
Vasya Tyorkin? Who is that? \\ Let us say quite clearly: \\ Very much a man who is \\ Unique-absolutely.
}

18 Faust, "Race, Gender, and Confederate Nationalism," 301.

19 In 1975 Vladimir Lakshin wrote of the "thrilling years of 1956 to 1961, when the Stalinist 'cult of personality' was denounced, when the whole cleansing process implied by that vague phrase began." In contrast, he characterizes the post-Khrushchev period as "a difficult time" for the Soviet intelligentsia. See Lakshin, "Solzhenitsyn, Tvardovskii i Novyi Mir," 85.

20 These comic strips were modeled on traditional folk lubki and on ROSTA posters from the early 1920s. During World War II Tyorkin again became a "collective" hero when artist Veniamin Briskin teamed up with Samuil Marshak to create the poster "How Vasya Tyorkin 'Camouflaged' the Fascists." Other authors and filmmakers used the character as well. For the poster image and discussion of Tyorkin see Bird, "The Functions of Poetry," 99-101. 
Despite a surname such as this,

Plain and unassuming,

Untold fame-a hero he-

Ever will be looming.

You might ask us straightaway,

A reasonable query:

Why it is that he is called

Vasya-not Vasily!

'Cause he is so dear to all,

'Cause all kinds of people

Get on famously with him,

'Cause they love that Vasya.

A bogatyr', his shoulders wide,

The lad's well put together.

By nature he's a cheery soul,

A man with guts and know-how.

In battle or wherever he is-

One thing is for certain:

First things first, he eats his fill,

Vasya knows his habit.

But he doesn't spare an ounce

Of his strength so fabled

And the enemy he stabs

Like wheat sheaves with a pitchfork.

Nonetheless, fierce as may be

Our fellow Vasya Tyorkin,-

Without a joke, without a pun

He can't survive a moment... ${ }^{21}$

21 "Vasia Tyorkin na fronte," Frontovaia biblioteka gazety "Na strazhe Rodiny" (Leningrad: Iskusstvo, 1940). 
This hero Vasya Tyorkin has the characteristics of a folk bogatyr-strong, broad-shouldered, quick with his bayonet-but also the endearing peasant qualities of cheerfulness, lightheartedness, and a good appetite. In his love of joking, songs, and puns, Vasya Tyorkin did not differ all that much from the original Vasily Chapaev, of whom Furmanov wrote: "To him, songs were like bread and water; Chapaev was always gloomy without singing. [When he felt] depressed, he couldn't live a whole day [without it]." 22

His name, the chummy Vasya, shows him to be not just a lover of jokes but the butt of jokes as well. The stories in which he was featured-the first written by Tvardovsky, later ones by others of the collective authors-were always illustrated, and Tvardovsky commented later that "they give an impression of naiveté, featuring Vasya's extremely improbable 'feats', and their humor is of questionable quality" ("Kak byl napisan," 238). Soon after the project began, the collective went their own journalistic ways, and the Red Army poet A. Shcherbakov took over as the main author of "Tyorkin."

While the stories were popular, the inventors of Tyorkin themselves believed them to be hack work: "We did not consider this to be literature," recalled Tvardovsky ("Kak byl napisan," 239). Nonetheless, the "improbable 'feats"' in wartime made this hero a Soviet hero.

Tvardovsky must have seen this potential in him because by 1940 he had decided to write a new version of Tyorkin, one who would be more than just a character from the funny pages:

"Tyorkin," according to the idea I then had, should combine approachability and flexibility of form-inherited directly from the newspaper "Tyorkin" - with a certain seriousness and even lyricism of content. In thinking about "Tyorkin" as a complete work, a poem, I now tried to pinpoint, to seize that "necessary plot moment" . . . without which I could not begin.

The problem with the "old Tyorkin," I now realize, was that it came out of a very old tradition, when any poetic word addressed to the masses was deliberately simplified and lowered to the specific cultural and political level of the reader. ("Kak byl napisan," 240)

22 Quoted in Sarra Shtut, Kakov ty, Chelovek?: geroicheskoe v sovetskoi literature (Moscow: Sovetskii pisatel', 1964), 147. 
In his essay "How 'Vasily Tyorkin' Was Written (An Answer to Readers)," Tvardovsky goes on to discuss how his attitude toward this "folk poetry" changed; instead of seeing it as work done with the left hand, as hack work, he came to believe in its inherent worth as a creation for a new kind of reader-the mass audience of the Soviet generation:

Now [readers] were the children of those revolutionary warriors for whom D. Bedny and V. Mayakovsky had written their songs, chastushki [song rhymes] and satirical couplets; they were literate, politically sophisticated, culturally aware people who had grown up under Soviet power. (“Kak byl napisan," 240)

In a word, the children of Chapaev, ready to move into the adult world as his full-fledged comrades.

The search for heroic exemplars from Russian military history to inspire the Soviet people received sanction from above. In his November 7, 1941, speech, Joseph Stalin himself invoked Russian military heroes in trying to encourage the populace: "May you be inspired in this war by the courageous figures of our great ancestors: Alexander Nevsky, Dmitry Donskoy, Kuzma Minin and Dmitry Pozharsky, Aleksei Suvorov and Mikhail Kutuzov!"23 Konstantin Simonov wrote poems in 1938 and 1939 on the twelfth-century Russian hero Alexander Nevsky and the eighteenth-century general Suvorov. But though he mentioned Suvorov in Vasily Tyorkin, Tvardovsky chose to focus on a smaller hero, a simple man to whom the front-line soldier could relate..$^{24}$

23 Qtd. in Nina Tumarkin, The Living and the Dead: The Rise and Fall of the Cult of World War II in Russia (New York: Basic Books, 1994), 63. Suvorov was the equivalent of "hero" and "warrior" for Soviet and pre-Soviet discourse. In Mayakovsky's satirical play The Bedbug, for example, Ivan Prisypkin claims to have fought the Revolution and Civil War "for the good life .. . Maybe I can raise the standards of the whole proletariat by looking after my own comforts!" In response, a true "proletarian" scoffs at him: "There's a warrior for you! A real Suvorov!" (Mayakovsky, The Bedbug and Selected Poetry, ed. Patricia Blake, trans. Max Hayward and George Reavey [Bloomington: Indiana University Press, 1975], 259).

24 Some scholars have called him an "antihero," though I don't agree. See Tumarkin, who calls Tyorkin the "most widely beloved of wartime personages" but depicts him as "a comic figure and an antihero, simple, mundane, organically bonded to the Russian land" (80). Sheila Fitzpatrick, too, describes Tyorkin as "an anti-hero who possesses all the foraging and survival skills needed by Homo sovieticus [with] the same good- 
Until June 22, 1941, the day that war broke out with the Germans, Tvardovsky had found himself frustrated. As he later described it, formal issues kept getting in his way, and because there was no real "need" for his character (no "social order," in the phrasing of socialist realism), he was having trouble with his writing. While Tvardovsky contrasted his "peacetime mood" with his more urgent need to write in time of war, his writer's block stemmed from a set of real problems. First, while official statements had encouraged the reintegration of folklore into Soviet culture since Gorky's 1934 speech at the First Congress of Soviet Writers, Tvardovsky was hesitant to start a long poèma in the style of nineteenth-century poet Nikolai Nekrasov or other truly folk literary productions. Second, though he loved his folk hero, that very human quality meant that the character did not seem serious enough to star in a long narrative poem. Likewise, the trochaic tetrameter he had chosen had no precedent in "big" poems and thus also seemed too trivial. Finally, and perhaps worst of all, he couldn't settle on a plot.

With war declared, Tvardovsky's poem gained a purpose, and his muse returned. As he recalled some years later:

When I decided to break with all my internal feelings of responsibility toward the conventions of form and turn my back on any potential evaluations from literary critics, then I felt free and easy. ${ }^{25}$

Tvardovsky would answer to soldiers and workers in wartime factories, not to sterile critics and literary traditions. He wrote Tyorkin for them, and surely one of the most remarkable things about the poem was that it was written and read while the war raged-in real time, as it were.

humored contempt for authority as Jaroslav Hasek's Good Soldier Schweik" (Sheila Fitzpatrick, "Everyday Stalinism: Ordinary Life in Extraordinary Times," excerpted in David L. Hoffmann, Stalinism: The Essential Readings [Malden, MA: Blackwell, 2003], 169). In contrast, Alexandra Smith identifies the poem as "one of the most typical pieces of Socialist realist writing, portraying a positive super-hero and conveying the sense of moral victory for the Socialist notion of 'collective man"' (Alexandra Smith, "Tvardovskii," in Neil Cornwell, ed., Reference Guide to Russian Literature [Chicago, London: Fitzroy Dearborn Publishers, 1998], 853).

25 Tvardovskii, "Kak byl napisan," 259. Tvardovskii might have benefitted from the advice Anton Chekhov is reported to have given actresses: "Don't think about the reviews, think only about what you are trying to accomplish on stage." 
Tvardovsky's timing was perfect, and his poem ideal for its moment. Knowing that it would be published in chapters or even smaller sections in army newspapers, and that his readers in between marches and battles might have only a short time to glance at individual excerpts, Tvardovsky designed the work deliberately so that each part was self-sufficient. A soldier could pick the poem up at any point, even if the previous installation had not reached him. Tvardovsky reminisced about imagining the book published between paperback covers, so the soldier could roll it up and stash it in his boot, hat, or inside his greatcoat, opening it for a few moments at any page when he had a chance. The rhythms of war created the form of the poem.

The result was a series of semi-disconnected chapters, each of which focuses on an important aspect of army life, interspersed with a number of meta-literary chapters from the author. Certain refrains appear, including one that emphasizes the importance of soldiers' work. Numerous chapters repeat the same lines: "A battle rages, right and holy. / A mortal battle not for glory, / But for life on this earth" (from "The Crossing," 34); "A terrible battle rages, bloody, / A mortal battle not for glory, / But for life on this earth" (from "About the Medal," 52); "On the left—the front, on the right—the front, / And in the snowy February gloom, / A terrible battle rages, bloody, / A mortal battle not for glory, / But for life on this earth" (from “The Duel," 84). Terrible, holy, bloody. These adjectives both depict and elevate the war experience, and Tvardovsky's refrain of "for life on this earth" (a refrain highlighted by virtually all critics and commentators on the poem) participated in the rhetoric of podvig and placed the military engagement in epic time. ${ }^{26}$

Shining with the aura of a holy truth, the "mortal battle" transformed the simple acts of the knowing trickster Vasily Tyorkin into a mandate for the inevitable successes of a messianic people on a quest to defeat the enemy, expressed through that same rhetoric of podvig. The sacred nature of the Red Army's task during the patriotic Great Fatherland War was also highlighted in such works as the "battle hymn" of the war, Vasily Lebedev-Kumach's reappropriated "Holy War," published in Izvestia on June 24, 1941, and set to music the following day-which struck some then and now as ironic, given the officially atheist state that was adopting it. "Holy War" almost teems with capital-letter concepts:

26 Compare with Boris Slutskii's poems, which avoided the rhetoric of podvig in favor of simplicity. 
Rise up, vast land, / Rise up for a fight to the death! / With the dark forces of fascism, / With the accursed horde. / Let noble fervor / Swell like a wave,-_ / A people's war is raging, / A holy war! ${ }^{27}$

Fight to the Death. Dark Forces of Fascism. Accursed Horde. Noble Fervor. People's War. Holy War. These words screamed out in capital letters that the war was indeed a repeat of the original Fatherland War of 1812, a sacred task to save Russia, taken up now by the new atheist state.

In his poem, Tvardovsky accessed that "heightening" impulse but combined it with the simple language and matter-of-fact cheerfulness of his hero to lower the tone of the sacred call and make his poem more believable and, in the end, more lasting. The rhetoric of podvig plus the application of byt proved a more appealing formula for readers.

As the writers' collective had mentioned in their early poems, Tyorkin is a common name. In fact, many soldiers wrote to Tvardovsky, convinced that the Tyorkin about whom he wrote, or another prototype for the hero, served with them in their battalion. Tyorkin was rooted in the everyday specifics of the lives of ordinary soldiers. Tvardovsky himself acknowledged the truth of his readers' reactions while denying their claims:

No, Vasily Tyorkin, as he appears in the book, is a completely invented persona, the fruit of the imagination, a creation of fantasy. And although he does have features which I observed in many living people, it is impossible to call a single one of those people Tyorkin's prototype. (“Kak byl napisan," 230)

These readers' reactions testify to the success of his characterization. Both specific and collective, Tyorkin seemed psychologically "real" to his readers and, we can hope, thus fulfilled his creator's goal of cheering on his soldieraudience in their daily fight with the enemy. While refining the character of Tyorkin, Tvardovsky worked out what he felt the audience, and the theme, needed:

The (external) "coloring" of frontline life was available to all. Cold, hoarfrost, shell explosions, bunkers, ice-covered army tents-A and

27 For more on Lebedev-Kumach and this song, see Hodgson, Written with the Bayonet, 57. 
$\mathrm{B}$ are writing about this as well. But they don't have the thing which I don't have yet either, or which I'm just hinting at-a person in the individual sense, "our lad," - not abstracted (on the plane of the "epoch," the country, and so on), but alive, dear, and difficult. ("Kak byl napisan," 246-247)

"Our lad" brings the poem down to earth, to a concrete, prosaic earth where he meets with jokes and laughter and with danger and disappointments. This is the rhetoric of podvig combined with the rhetoric of est' ${ }^{28}$

Tvardovsky was well aware that a literary hero in wartime would inherently beg comparison with the famed Civil War hero Vasily Chapaev. In the text of the poem at one point, a Chapaev-like lieutenant ("a cheerful fellow, a dancer, a Cossack" who has a "boyish mustache") rushes to lead the lads into battle: "There he is at the far hut / He raises his hand to his mustache: / "Bravo! Forward, boys!" / He shouted as dashingly, / As if he were Chapaev himself." But the cavalry officer, who leads the troops into battle, himself falls rather quickly. "The commander is wounded!" the soldiers cry. "Forward, boys!" he answers. "I'm not wounded. I am killed. ..."

In his place, Vasily Tyorkin steps up, and the platoon follows him instead, all forty of them as one. When the general tries to sort out who was the hero at the end of the day, the rest of the platoon explains, "He can't appear himself / He's badly wounded. . . . And then of all the surnames, / All the names of today, / "Tyorkin," they shouted, "Vasily!" / It was, of course, he" (Vasily Tyorkin, 147-51).

Although Tyorkin, unlike Chapaev, was not based on the biography of a real soldier, Tvardovsky saw that he was the hero for this particular war. The "Cossack," the "dapper lieutenant" of the Civil War, was not the man of the hour anymore; the peasant-soldier Tyorkin was. Tvardovsky worked on building him a "biography" to underpin his characterization. His notebooks detail how he conceived of this task:

28 As Grishunin notes, "The general direction of the great war is never forgotten in the details of byt, the events of the day" ("Vasily Tyorkin," 422). This forms a contrast with both Boris Slutskii and Viktor Nekrasov. Nekrasov in particular avoids the "general direction," allowing the reader to focus on the details instead. See chapter 4 below. 
There needs to be more of the hero's early biography. It must come through in his every gesture, action, story. But I must not simply give it outright. It's enough to think it through and imagine it for myself. (“Kak byl napisan," 247)

The other missing part in the Tyorkin tale is the "sidekick," in buddy-film terms, or the personification of political consciousness, to use the terms of socialist realist fiction. Chapaev went through the war with his commissar, Klychkov, showing him the way; and even in the later series of Chapaev jokes (which left out the political commissar entirely), Chapaev had his faithful adjutant, Petya, at his side. Tyorkin too needed a partner.

Tvardovsky recognized this as an issue of literary construction: "Another problem is that such 'amusing,' 'primitive' heroes are usually paired for contrast with a real, lyrical, 'elevated' hero. [I need] more digressions, more of myself in the poem" ("Kak byl napisan," 247). In other words, Tvardovsky decided that the author figure could serve as the missing partner. He supplied that partner in "digressions," which included a number of "From the Author" chapters, and through them Tvardovsky came to serve as his hero Tyorkin's mate.

Furmanov used the character of the political commissar Klychkov as an autobiographical stand-in, and his perspective informs the narrative of Chapaev. But Tvardovsky does the same thing without politicizing or indeed incarnating his stand-in. As one critic describes it:

In the Book about a Warrior besides the protagonist, Tyorkin, there is a second hero. This hero is the author-poet himself. He "made friends," became kin to Tyorkin, and travels everywhere with him ("Tyorkingoes on. The author-after him"). ${ }^{29}$

"The author," he explains, "is an intermediary between the hero and the reader, leading a free conversation with readers, whose presence is also felt." ${ }^{30}$ The presence of this authorial character, especially in a work written in rhyme,

29 Grishunin, "Vasilii Tyorkin A. Tvardovskogo," 434.

30 The critic compares the "author" character in Vasilii Tyorkin to the autobiographical "narrators" of Romantic works such as Pushkin's Eugene Onegin, Lermontov's Hero of our Time, suggesting that Tvardovskii added authentic data from his own biography to make his invented character Tyorkin seem more real. Grishunin, "Vasilii Tyorkin A. Tvardovskogo," 435. 
allowed readers to accept the folk poetry aspect of Vasily Tyorkin while also feeling that it was grounded in the reality of the 1940s.

Even émigré Russian author Ivan Bunin was enthusiastic about Vasily Tyorkin, ${ }^{31}$ in part perhaps for the same reason Soviet readers loved him and the poem. Vasily may be one of "our lads," but the author is a "known" quantity, and the two together give the sensation of authentic truth, of literature that reflects reality and remains contiguous with life and war. Tyorkin combines the rhetoric of podvig with the rhetoric of est' in a thoroughly convincing way, using details of everyday life, of byt, to ground the narrative.

\section{Death and the Warrior}

Even before creating the hero, and before the onset of war with Germany, Tvardovsky identified the plot elements he imagined including in his epic poem:

I [even] imagined my hero's path at certain moments of the poem. Crossing the border, being wounded, hospitalization, catching up to his unit that had already gone far ahead. Participation in decisive battles, some kind of meeting with a girl... ${ }^{32}$

Narratives about war frequently include these plot elements-crossing borders (especially rivers), participating in battles, being wounded and treated in the hospital, even a fleeting love interest. War narratives, in that sense, mirror the events of war, and the four outcomes in fiction are the same as in war itself: injury, captivity, survival, or death.

Over the course of the Second World War, the Soviet army is estimated to have lost somewhere between eight and ten million soldiers. ${ }^{33}$ Some of the

31 Bunin praised especially Tvardovskii's “unusual popular soldier's language." Letter to Teleshov, 10 September 1947, quoted in O. N. Mikhailov, "Put' Bunina-khudozhnika," Literaturnoe nasledstvo, vol. 84, part 1, Ivan Bunin (Moscow: Nauka, 1973), 53.

32 20.IV.1940. Tvardovskii, "S Karel'skogo peresheika (Iz frontovoi tetradi)," in Vasilii Tyorkin, 284.

33 See http://users.erols.com/mwhite28/ww2stats.htm. This site and the related http://users.erols.com/mwhite28/warstat1.htm, part of the Historical Atlas of the Twentieth Century put together by Matthew White, try to take published estimates and create an "average," neither too exaggerated nor dismissing the large casualty numbers out of hand. In his book Bloodlands, Timothy Snyder includes Soviet 
worst losses occurred early in the war, but the death toll continued through to the very last days.

Death looms large in wartime, and it is a common ending to the "narrative invention" of war, to borrow again from Drew Faust. Survivors, among them many of our authors and many thousands of veterans, struggled during and after the war to figure out their own relationship, both to that "narrative invention" in which many had participated personally and to those who remained on the battleground, drowned in river crossings, perished in POW and other camps, et cetera. As Kali Tal has argued, "To be a survivor is to be bound to the dead. ..." (229). The survivors strove, each in his or her own way, to understand that bond and to create meaning from violence and death.

When they used art to create that meaning, it had a variety of purposes: to lighten the load of the overwhelmed and overburdened soldier, to commemorate and memorialize the trauma experienced by the land and people, to fix physical and psychological experiences on the page and try to make sense of them, for themselves and for their readers. In the Soviet case, this became for many poets and writers a lifelong task, especially as changing political circumstances over the second half of the twentieth century in Russia altered the picture of "purpose and legitimation" for World War II. ${ }^{34}$

Let us notice, however, that in his initial list of possible plot nodes for his poem about Tyorkin, Tvardovsky did not mention death. He faced a certain genre problem: on the one hand, death was omnipresent in war, but on the

prisoners of war and besieged citizens (over four million) in the death count, as well as partisan casualties in Belarus and Poland (half a million dead) (Timothy Snyder, Bloodlands: Europe Between Hitler and Stalin [New York: Basic Books, 2010], 380).

34 The rhetoric of podvig continued when Soviet rhetoric and the Soviet Union itself were only a historical memory. See for example Aleksandr Boiko, "Geroi strany, kotoroi net," Sovetskaia Rossiia (16 February 1995), who reiterates the numbers, nationalities, and names of "heroes of the Soviet Union" in the face of "New Russians" who do not seem to value the sacrifice of his generation and the "victory which we have, alas, ingloriously squandered." He highlights the "boys of '23" - the first born in the Union of Soviet Socialist Republics (founded at the end of December 1922) - who were eighteen when the war began. Ninety-seven percent of this generation, according to Boiko's count, lost their lives in World War II. We will look at the "boys of '24" in chapter 7. 
other hand, he was writing an amusing, cheerful poem to keep the warriors' spirits high.

Throughout the poem, rumors fly from time to time of the hero's demise, and from the very start the author hints that a potential outcome for his hero is death. In the introductory section, one of several entitled "From the Author," the narrator presents his book as being incomplete, mere fragments of the saga of this hero:

What else? That's about it. / In a word, a book about a warrior. / Without beginning and without end. / Why without beginning? / Because there's no time / To start it from the first. / Why with no end? / I just pity the hero. (Tvardovskii, Vasilii Tyorkin, 7)

Inherent in the subtitle, "A Book about a Soldier" (kniga pro boitsa), is its rhyme, "without an ending" (bez kontsa). Here Tvardovsky is deliberately violating genre conventions; after all, a book about a hero should be biographical, should describe the natural life arc from birth to death. In wartime, though, there's no time for the details of early life, and the ending is almost inevitably tragic. ${ }^{35}$ As we have mentioned, millions of Soviet soldiers saw their lives end before the war did; Tyorkin was in danger as well. As the poem's narrator states a few chapters on:

By the way, we should just add / Our hero's hale and hearty for now, / But of course he's not charmed, / Against any damned shrapnel, / Any damned bullet, / That might happen, / As it were, to fly blindly, / If he's exposed,- - that's the end, brother. (88)

This attitude toward death (in calling names-“damned shrapnel," "damned bullet" ["oskolok-durak," "duratskaia pulia"]) is marked by a certain bravado but is a far cry from "scorn of death." Later the narrator draws a parallel be-

35 Iu. Burtin has noted that the poem had to be plotless, because a plot would have "inevitably transformed Tyorkin's fate into some kind of individual biography, and thus destroyed the book as a work of 'universal' front content." See Iu. Burtin, "Nestareiushchaia pravda," 136-153 in "Zhivaia pamiat' pokolenii." Velikaia Otechestvennaia voina $v$ sovetskoi literature. Sbornik statei (Moscow: Khudozhestvennaia literatura, 1965), 150-151. Tvardovskii's narrator says the same thing: "During war there's no plot" ([Tvardovskii, Vasilii Tyorkin, 87]). 
tween Tyorkin and the war, acknowledging that Tyorkin is not "real": "Tyorkin's not subject to death, / Until the war is at an end. ..." (174).

Though as a character Tyorkin became a beloved companion to soldiers at the front as well as in the rear, Tvardovsky regularly comments on his folkloric nature, calling him a "Russian miracle-man" (276) and a bogatyr and implying that his very function is tied to war; even Tyorkin himself states, "When I die, the war will end too."36

In the poem, as one critic has commented, death in wartime "is shown as an ordinary and even quite likely [event]": "If they kill you, your dead body, / Will lie with others in a row, / They'll cover you / With your worn greatcoat,-sleep, soldier." ${ }^{37}$ This attitude toward death is not presented in any kind of elevated, heroic tones, but as merely the result of the facts on the ground; in the end only two of every three soldiers returned from the war at all. Tvardovsky also emphasizes the randomness of death in battle. For example, in the chapter about crossing the river ("Crossing," or pereprava, which rhymes with glory [slava], but as the poet points out, the two are not synonymous): "Some will be remembered, some will get glory, / And some will [slip into] the dark water, - / Without a sign, without a trace." $(26)^{38}$

In the chapter "Death and the Warrior," the poet presents Tyorkin's struggle with death almost as a seduction, both physical and intellectual. The soldier lies on the battlefield ("not picked up" ["nepodobrannyi"]), quite literally on his deathbed. As Death (feminine, of course) leans over him, she offers her friendship/sexual partnership, saying, "Well, soldier, come with me. / I'm your [girl] friend now...." Tyorkin resists ("Tyorkin shuddered, freezing / On his snowy bed") and claims to belong to the living. In a cruel rhyme, Death addresses the warrior as a folk hero, evoking the epithet "good hero" (dóbryi mólodets) only to assure him that he is a "goner": "Death, laughing, leaned down further: / 'Enough, enough, young hero, / After all, I know, I can see: / You're alive, but not long for this world."' 39

36 In the poem, a wounded soldier is reported as having heard the following lines, with their convincing internal rhyme: "Tyorkin said at that moment: / When I die, the war will end” (“Молвил Теркин в ту минуту: / "Мне-конец, войне конец"” [Tvardovskii, Vasilii Tyorkin, 174]).

37 Quoted in A. L. Grishunin, “Vasily Tyorkin A. Tvardovskogo," 428-429.

38 The issue of memorialization deserves a much longer discussion and has received interesting treatments by writers and scholars alike.

39 Quotes above and below from this chapter in Tvardovskii, Vasilii Tyorkin, 151-59. 
In the poem's introduction, Tvardovsky had used the rhyme "hero / without an ending" (molodtsá / bez kontsá). Here he reiterates, using the voice of Death: the narrative may remain without an ending, out of pity for the doomed soldier, but Death speaks openly: this hero is not long for this world (molodets / ne zhiléts). The argument continues, with Death assuring the warrior that he has nothing to live for; even if he survives this night, what awaits him is more of the same: "cold, fear, exhaustion, dirt . ." not to mention "misery". And she argues that even if he survives the war, as he plans ("I'll fulfill my task, / Finish with the Germans, and head for home"), his return will be pointless. The war has destroyed the Russian land, and if he comes home an invalid, he'll be too weary and damaged to rebuild. Becoming numb, losing blood, Tyorkin is almost ready to give up and give in, "under one condition": he wants to come back on victory day. When Death refuses, he holds firm, following orders, as it were, never to surrender: "Then off with you, Cross-Eyes, / I'm a soldier who's still alive / I'll cry and howl with pain, / Perish without a trace in the field, / But to you I will never / Surrender willingly."

Tvardovsky uses these scenes with Death to enhance the folkloric quality of his character even while filling the narrative with wartime specifics, with byt. A burial detail comes out to collect Tyorkin's body and finds that he's alive, but Death does not lose hope that Tyorkin will die on the way back to the medical battalion. Eventually, she has to relent with a sigh, and the chapter ends with her defeat: "Those living ones, they're so / Very friendly among themselves. / That's why I have to manage / To come to terms with the ones who're alone." The power of the collective is reiterated: refusing to give in to Death's seductive arguments, Tyorkin maintains his connection with his fellow soldiers, who literally and symbolically share their warmth with him, placing their own mittens on his nearly frozen hands. Us and them, svoi and chuzhíe. Death remains "other," the enemy, and the soldiers' solidarity saves their comrade. The war is not yet over, and the hero will rise again.

In the hospital, Tyorkin maintains his trademark calm, jolly attitude, calling himself a "big fan of living." The moral that emerges from this narrative of Death's defeat is clear; brotherhood and unity are the mantra and the protection of the Soviet soldier: "If a third time an evil bullet / Pecks me to death, / Then at least I want to meet, / My final hour / Among you, brothers" (161). 
In the end Tvardovsky is unable to kill off his hero. At first he was certain to perish; then he survives two serious injuries (and is once left for dead), ${ }^{40}$ but as the war continues, the narrator expresses his hopes for an optimistic ending: "Leaving the ranks now? / Excuse me-Tyorkin lives! / Hale and hearty, more cheerful than before. / Dying? Just the opposite. / I'm now full of hope: / He'll outlive even me" (175).

Instead of chronicling Tyorkin's death, the "duel" in the chapter "Death and the Warrior" is more of a rhetorical struggle, or a struggle between potential seduction by a female and the brotherly bonds of Red Army men. In the end, instead of a corpse, the "brothers" discover that "the warrior is alive"!

In the Odyssey, Death is called "the great leveler":

Not even the gods

can defend a man, not even one they love, that day

when fate takes hold and lays him out at last. ${ }^{41}$

In the epic worldview of Homer, Death was all-powerful, but in Tvardovsky's world, the Warrior can rise from his deathbed-especially when surrounded by his comrades. Unity, cohesion, the collective are stronger than death; and the "duel" is not one-on-one, but Death against the entire Red Army.

Tvardovsky wrote for the soldiers in the field, every one of whom lived with the presence of death and with the knowledge, articulated or not, that they too might not return home. The character of Tyorkin was an honest representation of their potential fates, but he also gave them hope that they might survive. Throughout the war, for Tvardovsky and his readers, the hero served two purposes. First, Tyorkin lowered the expectations of what a true bogatyr was: "The bogatyr is not a fairytale hero- / A carefree giant, / But rather in his field uniform, / A man of simple stuff, / Who feels fear in battle..." (292). The hero can be afraid, but in his simplicity he gets the job done. "Yessir."

Secondly, Tyorkin was a companion and encompassed within himself all aspects of war: pain and fear, laughter and rest, wounds, even near-death

40 Tvardovskii recalled that he planned to end his work after Tyorkin's stay in the hospital: "Tyorkin fought, was wounded, and returns to his regiment," and that would be the end. "But my readers' letters taught me that I could not do this" (Tvardovskii, "Kak byl napisan," 264). Thus more and more chapters continued to appear.

41 Homer, The Odyssey, trans. Robert Fagles (New York: Penguin Books, 1996), 115. 
experiences, and, of course, podvig: "From Moscow to Stalingrad / You are invariably by my side - / My pain, my delight, / My rest and my feat" (224). For Tvardovsky, whose hero was embraced by thousands of soldiers, a "fadeto-black" ending turned out to be the most appropriate of all: "From whence he came, there too he vanished." 42 The folk hero Tyorkin did not perish after all but instead returned to the people, ${ }^{43}$ a new Chapaev for a new war.

42 Tvardovskii, "Kak byl napisan," 278. Vykhodtsev argues that Tyorkin in the poem came to represent the "people's immortality", and as such-according to the logic of the fairy tale or bylina-could not be allowed to die (Vykhodtsev, "A.T. Tvardovskii i narodnaia khudozhestvennaia kul'tura [Vasilii Tyorkin]," in Tvorchestvo A.T. Tvardovskogo: issledovaniia i materialy, ed. Vykhodtsev and N.A. Groznovaia [Leningrad: Nauka, 1989], 26).

43 In conjunction with the "continuation" of the tale of Tyorkin after the war, see Tvardovskii's discussions of popular works about his hero (Tvardovskii, "Kak byl napisan," 268-283), as well as chapter 5 below about his "Tyorkin in the Other World." 